\title{
Anaemia in juvenile chronic arthritis: serum inhibition of normal erythropoiesis in vitro
}

\author{
PETER J PROUSE, ANDREW R HARVEY, BRIAN BONNER, \\ CECIL D L REID, BARBARA M ANSELL, AND MICHAEL GUMPEL
}

From the Divisions of Rheumatology and Haematology, Clinical Research Centre, and Northwick Park Hospital, Harrow, Middlesex

SUMmaRY Serum from patients with juvenile chronic arthritis (JCA) was shown to inhibit colony formation by normal erythropoietic progenitor cells cultured in vitro. The inhibition was proportional to the degree of anaemia and to certain indices of activity of the arthritis and systemic disease. It occurred in a dose dependent manner with increasing serum concentration and was independent of previous blood transfusion or administered drugs. Erythropoietic progenitor cells from the bone marrows of anaemic patients with JCA showed normal requirements for accessory cells ( $\mathrm{T}$ lymphocytes and macrophages) in culture, and autologous accessory cells were not deficient in providing normal growth requirements.

Juvenile chronic arthritis (JCA) is the term used to describe a heterogeneous group of arthritic disorders of childhood ${ }^{1}$ in which anaemia is a common manifestation. The degree of the anaemia is related to the severity and type of the disease. ${ }^{2}$ Previous reports have shown iron deficiency, ${ }^{3}$ haemolysis, ${ }^{2}$ and erythroid aplasia ${ }^{4}$ to be causative factors in some patients, but in the majority no specific aetiology is demonstrated, and it is ascribed to the 'anaemia of chronic inflammatory disease'. ${ }^{5}$ There has been no investigation of this type of anaemia in children, but in adults with rheumatoid arthritis we have recently described a serum inhibitor of in vitro erythropoiesis. ${ }^{6}$

Techniques now available for in vitro culture of haemopoietic progenitor cells permit detailed investigation of the physiology of normal erythropoiesis and also of the mechanisms of such putative inhibition. The colony forming assay in semisolid medium allows differentiation and proliferation of primitive and more mature erythroid progenitor cells from the bone marrow. Small colonies of the more mature cell type develop after seven days in culture (colony forming unit erythroid, CFU-e), while large multicentric colonies of the more primitive cell (burst forming unit erythroid, BFU-e) develop after 14 days. ${ }^{7}$ BFU-e, but not CFU-e, can also be cultured from peripheral blood mononuclear

Accepted for publication 14 July 1986

Correspondence to Dr Peter J Prouse. Division of Rheumatology. Northwick Park Hospital, Watford Road, Harrow. Middlesex. cells. ${ }^{8}$ Optimal colony formation requires the presence of accessory cells, monocytes/macrophages, and $\mathrm{T}$ lymphocytes or their secreted products during the very early stages of differentiation and proliferation, ${ }^{910}$ whereas erythropoietin is active primarily on more mature erythroid precursors.

In a number of bone marrow failure states (pure red cell aplasia, aplastic anaemia) clonal assays have implicated inhibition of haemopoietic progenitors in the pathogenesis. ${ }^{11}$ Humoral inhibitors and suppressor lymphocytes have been demonstrated, and macrophages have been claimed to inhibit erythropoiesis in the anaemia of chronic infection. ${ }^{12} \mathrm{Re}$ cently, inhibition of BFU-e growth in vitro has been demonstrated in anaemic adult patients with rheumatoid arthritis (RA), ${ }^{6}$ and other evidence for such a mechanism has been put forward. ${ }^{1314}$ The object of this study was to examine the effect of serum from patients with JCA on normal erythroid progenitors and to seek to correlate this with the severity of the anaemia and disease activity. An additional study of JCA bone marrow cells in culture was performed to investigate whether progenitor cell-accessory cell interactions were normal and to examine the effect of autologous serum on marrow BFU-e development.

\section{Patients and methods}

PATIENTS

Serum was obtained from 31 patients with JCA (Eular-WHO criteria) ${ }^{1}$ who were selected by one of 


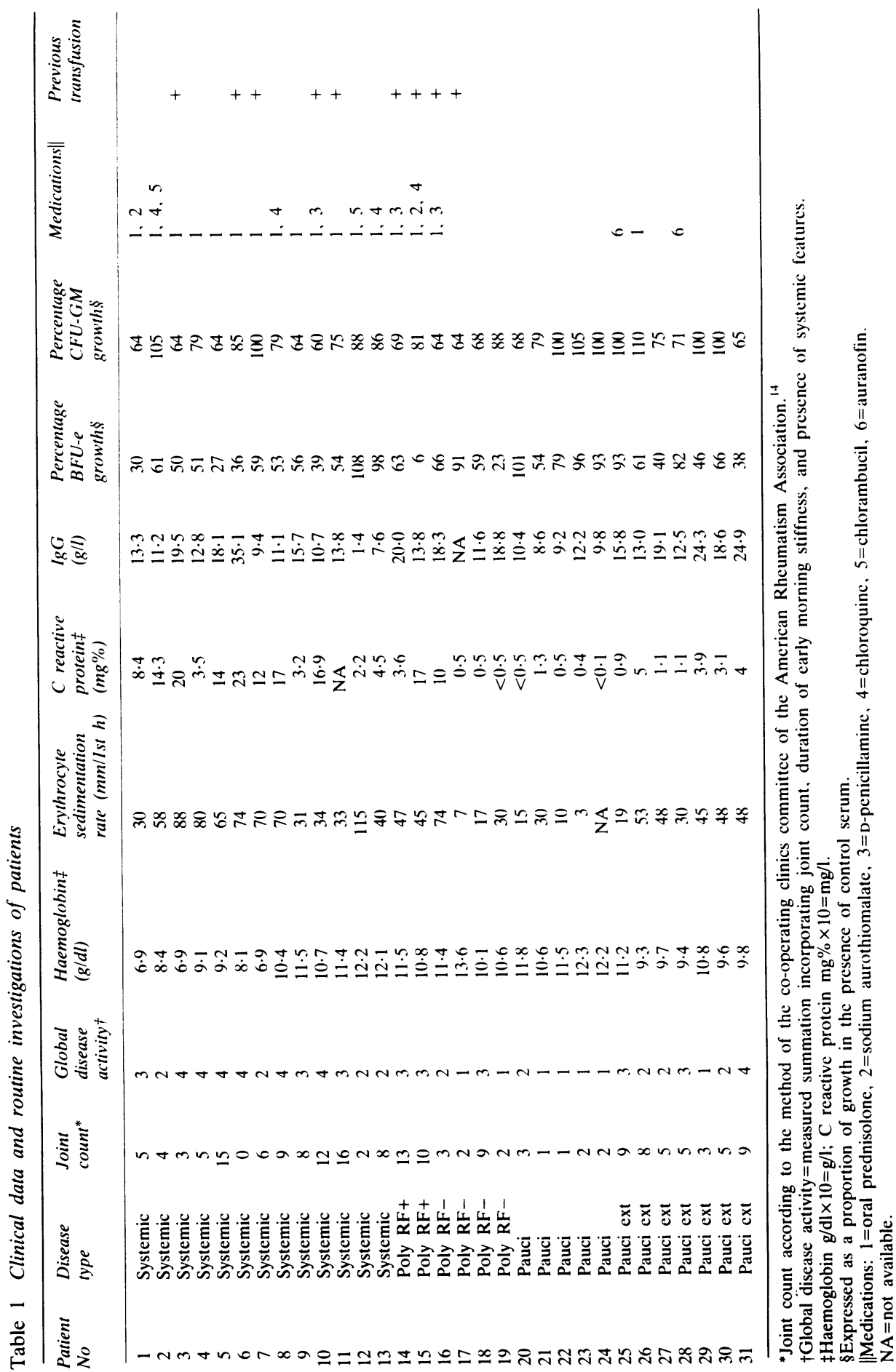


us (ARH) to give a range of disease type and activity and severity of anaemia. The disease type was subgrouped by the form of onset and disease progress into: systemic; polyarticular positive for IgM rheumatoid factor (poly $\mathrm{RF}+$ ); polyarticular negative for IgM rheumatoid factor (poly RF-); pauciarticular (pauci); and pauciarticular onset with extending joint involvement (pauci ext). Three of these patients with severe anaemia had bone marrow aspirations performed as part of their clinical investigation. In all patients faecal occult blood tests were negative. In three patients with a haemoglobin level below $11.5 \mathrm{~g} / \mathrm{dl}(115 \mathrm{~g} / \mathrm{l})$ serum ferritin levels were below $25 \mathrm{ng} / \mathrm{ml}(\mu \mathrm{g} / \mathrm{l})$ and, unlike the patients of Koerper et al, ${ }^{3}$ they did not respond to oral iron therapy. In the three severely anaemic patients on whom bone marrow aspirates were taken there were normal marrow iron stores. No patient had evidence of renal impairment, and other causes for anaemia were excluded. Clinical assessment of disease activity by one of us (ARH) was made with a count of active joints ${ }^{15}$ and a global assessment of disease activity in four grades, based on the severity of joint inflammation, duration of morning stiffness, and the presence and severity of systemic symptoms. Measurement of haemoglobin $(\mathrm{Hb})$, erythrocyte sedimentation rate (ESR, Westergren), serum C reactive protein (CRP, radial immune diffusion), immunoglobulin (laser nephelometry), and rheumatoid factor (latex, RAHA) were obtained. Two of the 31 patients were positive for rheumatoid factor. All patients were receiving non-steroidal antiinflammatory drugs and 19 were also receiving disease modifying drugs: prednisolone (17), sodium aurothiomalate (two), auranofin (two), chloroquine (four), D-penicillamine (three), and chlorambucil (two) (Table 1).

PERIPHERAL BLOOD STUDIES

Sera from the 31 patients with JCA were screened for inhibitory activity in the BFU-e colony forming assay by one of us (PJP) without knowledge of the clinical data. Group $\mathrm{O}$ peripheral blood mononuclear cells from five normal volunteers were prepared by Ficoll-Paque centrifugation, and after incubation in plastic tissue culture plates the nonadherent cell fraction (PB-NAC; $<5 \%$ macrophages present) was used as the source of erythroid progenitors (BFU-e) in methylcellulose culture at $5 \times 10^{5}$ cells $/ \mathrm{ml}$. Serum autologous with the PB-NAC or sera from patients with JCA were added at $10 \%$ final volume. Sera from five selected patients were titrated at varying saline dilutions to define the doseresponse relationship of the serum inhibitor. BFU-e colonies were counted at 14 days by direct vision using an inverted microscope. Myeloid colonies
(CFU-GM), identified by distinct morphology and absence of haemoglobin, were also counted at 14 days. BFU-e and CFU-GM counts were obtained from simultaneous cultures of PB-NAC with autologous or JCA sera; the counts obtained with autologous serum were designated as a standard $100 \%$, and the counts obtained with JCA sera as a proportion of that (percentage growth, Table 1). The mean colony count in control cultures for BFU-e was 50 (range 28-69) and for CFU-GM was 6 (range 3-8) per $5 \times 10^{5}$ PB-NAC.

BONE MARROW STUDIES

Bone marrow (BM) cells obtained from posterior iliac crest aspirates on three anaemic JCA patients were fractionated to provide two progenitor cell populations. After Ficoll-Paque centrifugation a mononuclear cell fraction non-adherent to plastic was prepared (BM-NAC; $<5 \%$ macrophages present). A proportion of these cells was subjected to $T$ lymphocyte depletion by a single neuraminidase treated sheep erythrocyte rosette technique, ${ }^{15}$ and virtually complete macrophage removal was achieved by centrifugation over a sucrose gradient (5-15\%, $100 \mathrm{~g}$ for seven minutes). ${ }^{17}$ This second progenitor population was designated as the low density fraction minus $\mathrm{T}$ lymphocytes (LDF, $\mathrm{T}^{\circ}$; $<1 \%$ macrophages). Coculture experiments to investigate the interaction of progenitor cells with accessory cells (adherent cell-macrophages and $T$ lymphocytes) were performed using autologous bone marrow adherent cells $(80-90 \%$ peroxidase positive) and autologous peripheral blood $\mathrm{T}$ lymphocytes $(95 \%$ sheep erythrocyte rosette forming cells) as previously described. ${ }^{6}$ LDF, $\mathrm{T}^{\circ}$ were cultured at $0.5 \times 10^{5}$ cells $/ \mathrm{ml}$, and adherent cells added at $0.2-0.8 \times 10^{5}$ cells $/ \mathrm{ml}$ or $\mathrm{T}$ lymphocytes added at $10 \times 10^{5} / \mathrm{ml}$ in $1 \%$ methylcellulose cultures. BFU-e growth from both BM-NAC and low density fractions in the presence of autologous or heterologous $\mathrm{ABO}$ compatible serum was examined for evidence of inhibition of growth by the autologous serum.

CULTURE DETAILS

All cultures were performed in $1 \%$ methylcellulose, Iscove's complete medium, $1 \%$ deionised bovine serum albumin (Sigma), $30 \%$ fetal calf serum (Sera Lab), $10^{-4}$ M 2- $\beta$-mercaptoethanol, and sheep step III erythropoietin (Connaught) at $2 \mathrm{U} / \mathrm{ml}$. Duplicate samples of all cultures were incubated in $5 \%$ $\mathrm{CO}_{2} / 95 \%$ air at $37^{\circ} \mathrm{C}$ in a fully humidified incubator until 14 days when erythroid bursts were counted.

Test human sera added to culture was not decomplemented before use.

STATISTICAL ANALYSIS

The relation between percentage BFU-e growth and 
130 Prouse, Harvey, Bonner, Reid, Ansell, Gumpel

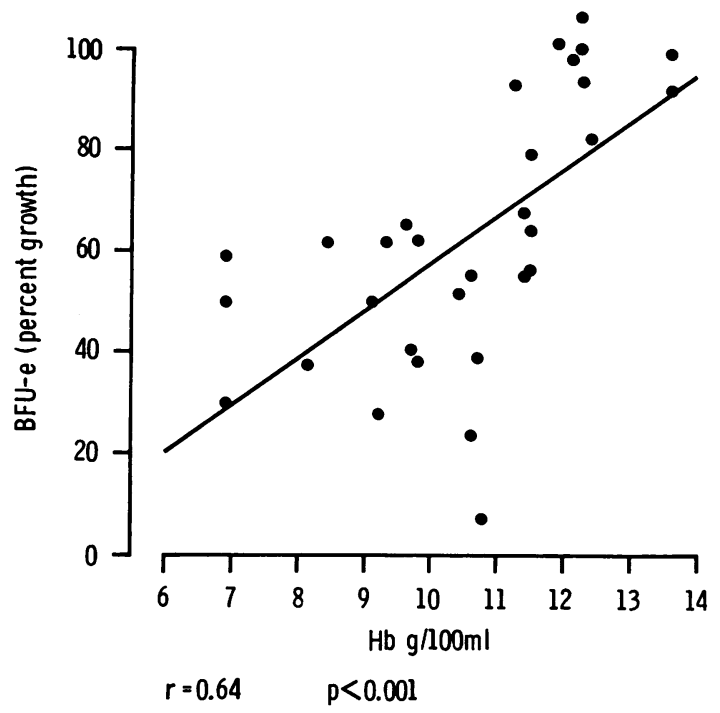

Fig. 1a

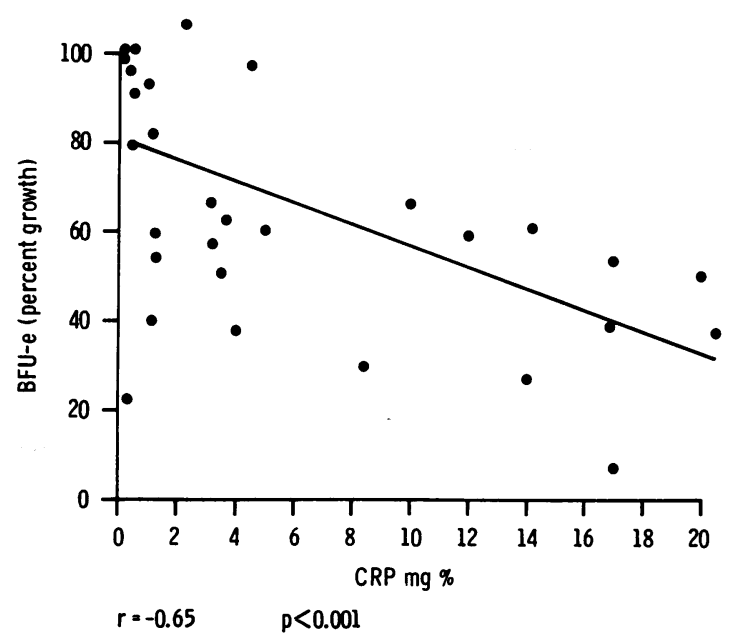

Fig. 1b

FIG. 1 Percentage erythroid bursts $v(a)$ haemoglobin ( $n=31)$, (b) CRP ( $n=30)$, (c) IgG ( $n=30)$, (d) articular index $(n=31)$. ( $\mathrm{Hb} g / 100 \mathrm{ml} \times 10=\mathrm{g} / \mathrm{l} ; \mathrm{CRP} \mathrm{mg} \% \times 10=\mathrm{mg} / \mathrm{l}$.)

the clinical and laboratory variable indices of disease activity was assessed for each patient by the linear regression method. In addition, using the GLIM computer program ${ }^{18} 14$ explanatory variables were investigated in various combinations to try to find a function that best fitted the observed percentage

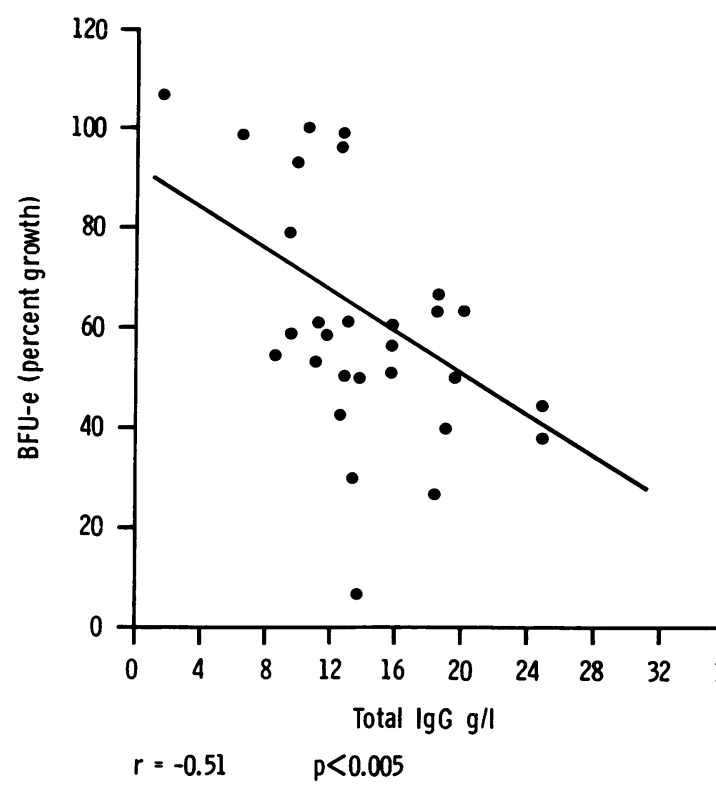

Fig. 1c

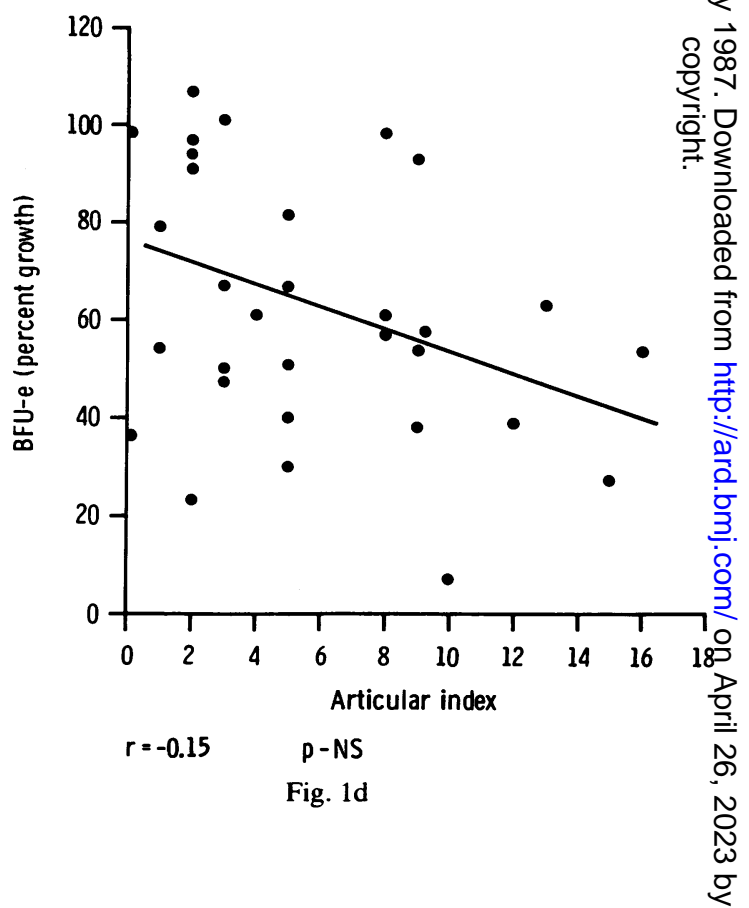

growth. The GLIM computer program is a general-co ised multiple regression method which was chosen $\overparen{\Phi}$ to allow the various possible combinations of these $\stackrel{\mathscr{C}}{+}$ variables to be considered in a multivariate way; to $T$ examine each one separately when the others were also involved could be seriously misleading. Vari- 
Table 2 Relation between disease severity, BFU-e, and CFU-GM growth in the presence of serum from 31 patients with JCA

\begin{tabular}{lll}
\hline Disease activity & $\begin{array}{l}\text { Mean percentage } \\
\text { growth of BFU-e* }\end{array}$ & $\begin{array}{l}\text { Mean percentage } \\
\text { growth of CFU-GM }\end{array}$ \\
\hline Mild (grade 1. $\mathrm{n}=7)$ & $73(29) \div$ & $77(19)$ \\
Moderatc (grade 2. $\mathrm{n}=8)$ & $73(23)$ & $90(17)$ \\
Severe (grade 3. $\mathrm{n}=8)$ & $55(30)$ & $74(12)$ \\
Very severe (grade 4. $\mathrm{n}=8)$ & $42(10)$ & $72(11)$
\end{tabular}

*The reduction in BFU-e growth is significant to the level $p=0.009$ (GLIM).

+Values are given as mean (SD).

ables of a yes/no type were coded as 0 or 1 , and the three missing values (Table 1) were replaced by averages of the appropriate variables to get a complete data set.

\section{Results}

The clinical data and routine investigations are summarised in Table 1 . Nineteen of the 31 patients were female. The mean age was 10 years (SD 6, range $2-31$, and only two patients were aged over 16 years at the time of study. ${ }^{17}$ The mean disease duration was $5 \cdot 3$ years (SD $4 \cdot 8$, range $0 \cdot 4-22$ ).

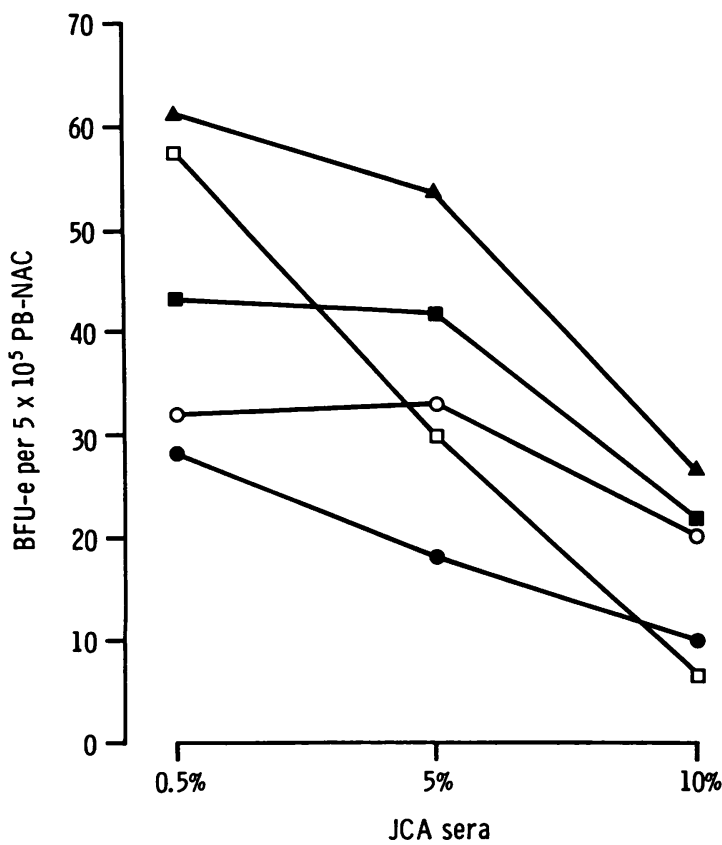

FIG. 2 Effect of JCA sera (five) in varying dilutions on erythroid growth from normal peripheral blood precursors.
EFFECT ON NORMAL PERIPHERAL BLOOD BFU-C GROWTH OF SERUM FROM PATIENTS WITH JCA

The addition of JCA serum to normal peripheral blood cultures reduced BFU-e growth, and the reduction occurred in cultures of mononuclear cells from each of the five donors. Plotting the results from all the experiments showed that the degree of inhibition corresponded significantly with the patients' haemoglobin level and with the CRP and total IgG levels (Figs 1a, b, and c). No correlation was found with the joint count alone (Fig. 1d), but the reduction in growth did significantly correlate with the overall assessment of disease activity (Table 2). The percentage growth for each serum sample is recorded in Table 1, and the individual relationships between percentage growth and $\mathrm{Hb}, \mathrm{CRP}, \mathrm{IgG}$, and joint count are illustrated in Fig. 1.

Further analysis of the variables listed in Table 1 by the GLIM program showed that the observed percentage BFU-e growth was best predicted by five factors: joint count $(p=0.020)$, haemoglobin $(p=0.029)$, IgG $(p=0.020)$, sodium aurothiomalate

Table 3 Reproducibility of inhibition of BFU-e growth* in the presence of patient serum $(10 \%)$ using mononuclear cells from separate donors

\begin{tabular}{llc}
\hline Patient sera & \multicolumn{2}{c}{ Percentage } \\
\cline { 2 - 3 } & Exp. 1 & Exp. 2 \\
\hline 1 & 30 & 25 \\
2 & 61 & 50 \\
3 & 50 & 62 \\
7 & 59 & 62 \\
11 & 54 & 38 \\
14 & 60 & 50 \\
18 & 23 & 35 \\
24 & 93 & 105 \\
27 & 40 & 50 \\
31 & 38 & 36 \\
\hline
\end{tabular}

${ }^{*}$ Expressed as a proportion of growth in the presence of control serum. 
$(p=0.008)$, and auranofin $(p=0.033)$. If haemoglobin was excluded then $C$ reactive protein replaced it for the best fit. The $p$ values represent the probability associated with the introduction of the given variable where the others are already included. The best linear function of the five variables gave an estimate of percentage growth that had a correlation of 0.84 with the observed value. The predictive value of sodium aurothiomalate and auranofin was found from only four patients, but the GLIM program took into account the low number of observations, and we believe this observation reflected the more severe disease activity of these patients.

The relation between percentage BFU-e growth and treatment with 'disease modifying drugs', prednisolone, and blood transfusion was analysed for each patient by the GLIM program and no significant correlation found.

Addition of increasing concentrations of known inhibitory serum to normal peripheral blood cultures produced increasing inhibition of BFU-e development (Fig. 2). This dose-response relationship is that of an inhibitor and would not be the result of the failure of normal serum stimulators of BFU-e.

The reproducibility of inhibition was tested by comparing the effect of sera from 10 of the 31 patients on mononuclear cells from separate donors, and a comparable degree of inhibition was found (Table 3).

Enumeration of myeloid colonies (CFU-GM) failed to show a reduction in numbers by patient serum that correlated with either the haemoglobin level (Table 1) or with disease activity (Table 2).

Table 4 Effect of autologous and control serum (10\%) on $B F U$-e growth from patient bone marrow cells $\left(0.5 \times 10^{5}\right.$ cells $\left./ \mathrm{ml}\right)$

\begin{tabular}{|c|c|c|c|}
\hline Patient & Human serumsnil & Control & Autologous ${ }^{\dagger}$ \\
\hline \multicolumn{4}{|c|}{$B M-N A C^{*}$} \\
\hline 1 & 54 & 57 & 44 \\
\hline 2 & 35 & 41 & 27 \\
\hline 3 & 28 & 34 & 19 \\
\hline \multicolumn{4}{|c|}{$L D F, T^{\circ}+0.4 \times 10^{5} M \phi,+10 \times 10^{5} T$ cells } \\
\hline \multicolumn{4}{|c|}{ Patient Human serum:control } \\
\hline & & \multicolumn{2}{|c|}{5} \\
\hline 2 & 36 & \multicolumn{2}{|c|}{14} \\
\hline 3 & 32 & \multicolumn{2}{|l|}{15} \\
\hline
\end{tabular}

${ }^{*} \mathrm{BM}-\mathrm{NAC}=$ non-adherent bone marrow cells; $\mathrm{LDF}, \mathrm{T}^{\circ}=$ nonadherent. low density fraction bone marrow cells depleted of $\mathrm{T}$ lymphocytes and macrophages (Mø).

tStudent's $t$ paired analysis for BFU-c growth $(n=6)$ in control $v$ autologous serum showed significantly better growth in control serum $(p<0.001)$.

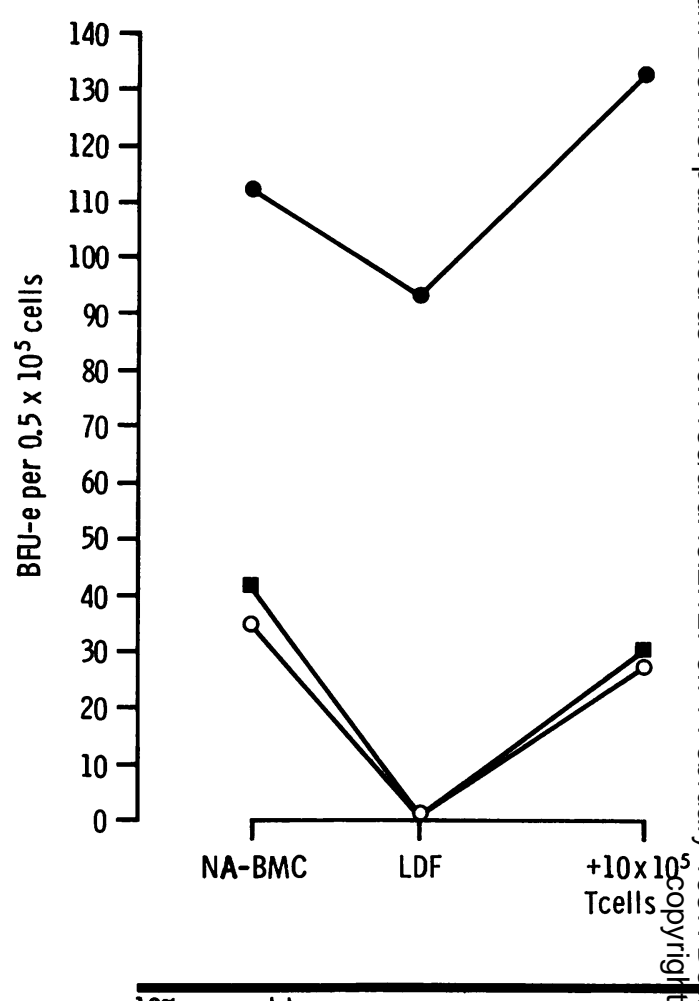

Fig. 3a

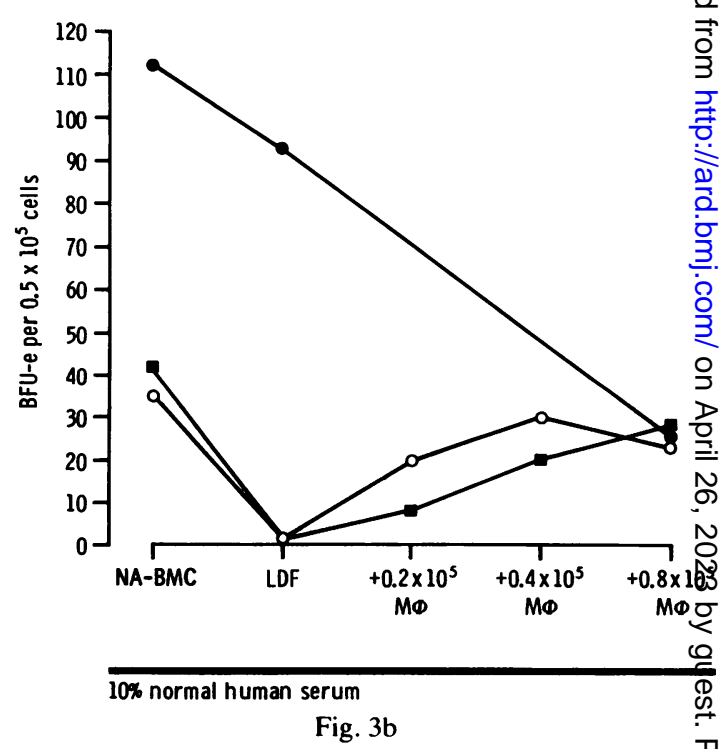

FIG. 3 Effect of (a) $T$ cell readdition and (b) macrophage $(M \phi)$ readdition on marrow erythroid burst formation. $L D F$ marrow $T$ cell and macrophage depleted. 
EFFECT ON AUTOLOGOUS MARROW BFU-C GROWTH OF SERUM FROM PATIENTS WITH JCA In the three anaemic JCA patients from whom bone marrow aspirates were taken the influence of autologous serum on BFU-e growth was compared with that of heterologous $\mathrm{ABO}$ matched normal serum. BFU-e numbers both from the BM-NAC and LDF cell pools were reduced by autologous serum. Pooling the results from all six cultures showed the reduction in growth to be significant (Table 4).

EFFECT OF AUTOLOGOUS ACCESSORY CELLS ON BFU-C GROWTH FROM PATIENTBONE MAR ROW

Cultures of bone marrow cells from three anaemic JCA patients gave optimum BFU-e derived colonies in the partially fractionated samples (BM-NAC), with marked reduction in colony counts in two of three samples after accessory cell depletion (LDF, $\mathrm{T}^{\circ}$ ). Reconstitution with autologous adherent cells or $\mathrm{T}$ lymphocytes restored colony forming capacity (Figs $3 \mathrm{a}$ and $\mathrm{b}$ ) apart from in one patient where adherent cell readdition resulted in macrophage colony overgrowth. Excessive numbers of macrophages have been described as inhibiting BFU-e growth. 1920

\section{Discussion}

Hypoplasia of the erythroid marrow is not a feature of the anaemia of chronic disorders. ${ }^{21}$ Unlike pure red cell aplasia the haemoglobin is maintained, albeit at a low level, and generally there are no transfusion requirements. In JCA, however, as in RA, the erythroid marrow does fail to expand in response to the anaemia with no appropriate increase in erythroblast numbers. In RA recent in vivo ferrokinetic data support the concept of an inadequate erythropoietic response to anaemia, ${ }^{22}$ and in addition, increased ineffective erythropoiesis due to death of haem containing progenitors within the marrow has been described both in vivo ${ }^{23}$ and in vitro. ${ }^{24}$ Inhibition of erythroid maturation could be responsible and occur at any point from the level of the primitive progenitor cell to the fully differentiated erythrocyte.

The in vitro formation of erythroid bursts from primitive BFU-e represents considerable maturation and proliferation which may be blocked at any stage, resulting in a diminution of colony numbers. Our results demonstrate serum inhibition of in vitro erythropoiesis and would be in keeping with failure of the erythroid marrow to expand and the development of the anaemia seen clincally.

Bone marrow cultures from our patients confirm a greater inhibition of BFU-e growth by autologous serum than with normal heterologous serum. The bone marrow cultures also show that colony forming capacity of the BM-NAC is retained, that it is reduced by the depletion of accessory cells, and stimulated by their readdition (Figs $3 a$ and $b$ ). This is in agreement with our findings in RA that autologous accessory cells were not deficient in providing growth factors. ${ }^{6}$

Inhibition of erythropoiesis corresponded with the severity of the anaemia and also with the disease activity, implying that it is produced as an integral part of the inflammatory process. Several mediators of the inflammatory responses have the capacity to inhibit cellular proliferation, and of these prostaglandins $^{25}$ and interferons ${ }^{26}$ may directly affect in vitro haemopoiesis. Although there is no evidence for inhibition of erythropoiesis by prostaglandins of the $E$ series, ${ }^{25}$ a prostaglandin $F 2 / \alpha$ glycoprotein complex has been described as inhibitory, ${ }^{27}$ and further information relating this finding to human inflammatory conditions is awaited.

Interferons (IFN) $\alpha, \beta$, and $\gamma$ have been shown to inhibit colony formation by human erythroid and myeloid progenitors, ${ }^{26}$ the greatest effect being on primitive erythroid progenitors. ${ }^{28}$ IFN $\gamma$, an in vivo product of activated $\mathrm{T}$ lymphocytes, has been suggested as the mediator responsible for $T$ cell mediated inhibition of haemopoiesis in some cases of aplastic anaemia. ${ }^{29}$ In JCA, IFN $\gamma$ could not be detected in serum even during acute exacerbation. ${ }^{30}$ This evidence, together with the lack of a T lymphocyte suppressive effect in our marrow coculture studies, suggests that an inhibitory role for INF $\gamma$ is unlikely.

An additional group of non-interferon inhibitors of cell proliferation released by antigen and mitogen activated lymphocytes has been described. ${ }^{31}$ Recent studies have shown a relation between these factors and natural killer (NK) cell activity; ${ }^{32}{ }^{33}$ NK cells have been reported to inhibit in vitro erythroid colony formation. ${ }^{34}$ These lymphotoxins show chemical and immunological similarities to immunoglobulin, ${ }^{35}$ and it is of interest that the serum inhibitor of in vitro erythropoiesis reported by Dainiak et al separated with the immunoglobulin fraction. 13

Previous investigation of the anaemia of chronic disorders has suggested that labile iron is unavailable for erythropoiesis. ${ }^{36}$ This process is related to inflammation $^{37}$ and interleukin 1 may be the mediator stimulating macrophages to trap iron. ${ }^{21}$ The patients with JCA and with the greatest degree of serum inhibition were those with active systemic disease, many of whose features are also thought to be mediated by interleukin $1^{38}$ Interleukin 1 , 
however, is highly unlikely to inhibit in vitro erythropoiesis by making iron unavailable, as excess iron is present in the culture medium and inhibition occurs when there are only low numbers of macrophages present in the cultures.

Clarification of the precise mechanisms of serum inhibition of erythropoiesis in JCA will require detailed studies using highly purified progenitor cell and accessory cell populations to elucidate the target cell and fractionation of the serum to permit physicochemical identification of the factor(s) responsible.

We thank Mr Arthur Howard for assistance with the assays for C reactive protein and serum ferritin levels and Dr I D Hill for the statistical analysis of this study. This work was supported by grant No G.31 from the Arthritis and Rheumatism Council.

\section{References}

1 Ansell B M. Chronic arthritis in childhood (Heberden Oration 1977). Ann Rheum Dis 1978; 37: 107-20.

2 Harvey A R. Pippard M. Ansell B M. Anaemia in juvenile chronic arthritis: the significance of microcytosis. Scand $J$ Rheumatol (in press).

3 Koerper M A. Stempel P A. Dallman P R. Anemia in patients with juvenile rheumatoid arthritis. J Pediatr 1978; 92: 930-3.

4 Rubin R N, Walker B K. Ballas S K. Travis S F. Erythroid aplasia in juvenile rheumatoid arthritis. Am J Dis Child 1978; 132: $760-2$.

5 Cartwright $\mathrm{G} \mathrm{E}$. The anaemia of chronic disorders. $\mathrm{Br} \mathrm{J}$ Haematol 1971: 21: 147-52.

6 Reid C D L, Prouse P J. Baptista L C, Gumpel J M, Chanarin I. The mechanism of anaemia in rheumatoid arthritis: effects of bone marrow adherent cells and of serum on in vitro erythropoiesis. Br J Haematol 1984; 58: 607-15.

7 Eaves C J, Eaves A C. Erythropoietin dose-response curves for three classes of erythroid progenitors in normal human marrow and in patients with polycythemia vera. Blood 1978; 52: 1196-210.

8 Clarke B J, Housman D. Characterisation of an erythroid precursor cell of high proliferative capacity in normal human peripheral blood. Proc Natl Acad Sci USA 1977; 74: 1105-9.

9 Reid C D L, Baptista L C. Chanarin I. Erythroid colony growth in vitro from human peripheral blood null cells: evidence for regulation by $\mathrm{T}$ lymphocytes and monocytes. Br J Haematol 1981; 48: 155-64

10 Clarke B J, Harvey A R, Kaiser J, Leeds C. Quantitative analysis of the role of accessory cells in the development of human blood BFU-c derived erythroid colonies. Exp Hematol 1984; 12: 250-65.

11 Zoumbos N. Gascon P, Young N. The function of lymphocytes in normal and suppressed hematopoiesis. Blut 1984: 48: 1-9.

12 Zanjani E D, McGlave P B, Davies S F, Banisadre M, Kaplan M E. Sarosi G A. In vitro suppression of erythropoiesis by bone marrow adherent cells from some patients with fungal infection. Br J Haematol 1982; 50: 479-98.

13 Dainiak N, Hardin J, Floyd J, Callahan M. Hoffman, R. Humoral suppression of erythropoiesis in systemic lupus erythematosus (SLE) and rheumatoid arthritis (RA). Am J Med 1980; 69: $537-44$.

14 Harvey A R, Clarke B J, Chai D H K. Kean W F, Buchanan W $W$. Anemia associated with rheumatoid disease. Inverse correlation between erythropoiesis and both IgM and rheumatoid factor levels. Arthritis Rheum 1983; 26: 28-34.

15 Co-operating Clinics Committee of the American Rheumatism Association. A seven-day variability study of 489 patients with peripheral rheumatoid arthritis. Arthritis Rheum 1965; 8? 302-34.

16 Gmelig-Meyling F. Baillieux R E. Simplified procedure for the separation of human T and non T-cells. Vox Sang 1977; 33: 5-8

17 deGast G C, Platts-MillsT A.E. Functional studies on lymphocytes? in adult human bone marrow. $J$ Immunol 1978; 122: 280-40

18 Baker R J, Nelder J A. The GLIM system manual, release $3 \frac{\square}{\square}$ Oxford: Numerical Algorithms Group Ltd, 1978.

19 Rinehart J J, Zanjani E D. Nomdedew B. Gormus B J, Kaplan M E. Cell-cell interaction in erythropoiesis. Role of human monocytes. J Clin Invest 1978; 62: 979-86.

20 Mangan K F. Desforges J F. The role of T lymphocytes and monocytes in the regulation of human erythropoietic periphera $\vec{b}$ blood burst forming units. Exp Hematol 1980; 8: 717-27.

21 Lee G R. The anemia of chronic disease. Semin Hematol $1983 \overrightarrow{\dot{\omega}}$ 20: $61-80$.

22 Cavill I, Bentley D P. Erythropoiesis in the anaemia of rheumatoid arthritis. Br J Haematol 1982; 50: 583-90.

23 Dinant H J, DeMaat C E M. Erythropoiesis and measured celp life span in normal subjects and in patients with the anaemia of active rheumatoid arthritis. Br J Haematol 1978; 39: 437-44?

24 Williams R A. Samson D. Tikerpae J. Crowne H. Gumpel J M $\vec{N}$ In-vitro studies of ineffective erythropoiesis in rheumatoid arthritis. Ann Rheum Dis 1982: 41: 502-7.

25 Kurland J, Moore M A S. Modulation of haemopoiesis by prostaglandins. Exp Hematol 1977; 5: 357-73.

26 Broxmeyer H E. Lu L. Platzer E. Feit C, Juliano L, Rubin B YФD Comparative analysis of human gamma, alpha and bet? interferons on human multipotential (CFU-GEMM), erythroi@్ (BFU-e) and granulocyte-macrophage (CFU-GM) progenito cells. J Immunol 1983; 131: 1300-5.

27 Lewis J P. Neal W A. Garver F A. Gardner E, Lutcher Partial characterization of an erythropoiesis inhibiting fagen [Abstract]. Exp Hematol 1984; 12 (suppl): 136.

28 Toretsky J A. Shanidi N J. Finlay J L. Effects of huma interferon gamma in hematopoietic progenitor cells [Abstract] Exp Hematol 1984; 12 (suppl): 108.

29 Zoumbos N C. Djeu J Y. Young N S. Interferon is th@ suppressor of hematopoiesis generated by stimulated lymphoक cytes in vitro. J Immunol 1984: 133: 768-74.

30 Bacon T H. DeVere-Tyndall A. Tyrrell D A J. Denman A M Ansell B M. Interferon system in patients with systemic juvenilg chronic arthritis: in vivo and in vitro studies. Clin Exp Immunof 1983: 54: 23-30.

31 Granger G A. Hiserodt J C. Ware C F. Cytotoxic and growt inhibiting lymphokines. In: Cohen S, Pick E, Oppenheim J TQ eds. Biology of the lymphokines. New York: Academic Press 1978: 141-63.

32 Weitzen M L. Yamamoto R S, Granger G A. Identification of human lymphocyte derived lymphotoxins with binding and ceßु lytic activity on NK-sensitive cell lines in vitro. Cell Immunof 1983: 77: 30-42.

33 Reidarson T H, Levy W E, Klostergaard J. Inducible mace rophage cytotoxins. 1 . Biokinetics of activation and release in vitro. JNCI 1982; 69: 879-87.

34 Mangan K E, Winkelstein A, Hartnett M E, Matis S A. Natura年. killer cells regulate human erythropoiesis in vitro. Clin ReNU 1982; 30: 773A

35 Amino N, Linn E S. Pysher T J, Mier P. Moore G E, DeGroon L T. Human lymohotoxin obtained from established lymphoif lines: purification characteristics and inhibition by antico immunoglobulin. J Immunol 1974; 113: 1334-5.

36 Konijn A M, Carmel N, Levy R. Hershko C. Ferritin synthesił in inflammation. II. Mechanism of increased ferritin synthesis Br J Haematol 1981; 49: 361-70.

37 Konijn A M. Hershko C. Ferritin synthesis in inflammation? Pathogenesis of impaired iron release. Br J Haematol 1977; 37:0 $7-16$.

38 Lachman L B. Human interleukin 1: purification and prop erties. Fed Proc 1983; 42: 2639-45. 